\title{
ECONOMICS AS CULTURE: SYNERGY OF ADVANCED DEVELOPMENT
}

\author{
Petro Kutsyk ${ }^{1}$, Bohdan Shevchyk ${ }^{2}$, Olena Perepolkina ${ }^{3}$
}

\begin{abstract}
Economic systems are viewed as sociocultural phenomena of an ontological order. The hypothesis of a trialectic-dual and attractional-level nature of the implementation of cultural-paternalistic projects in the institutional sphere of economic relations is put forward. Attractive high-order noumena shape/define lowerorder phenomena in paternal practices of economics. Attractive space is a bipolar space of regression. The algorithm of the actualization of the noumenon into a phenomenon is a triadic structure: axiological narrative paradigmatic project - praxiological pattern. Each paternal project is realized by means of a trialectical mechanism: organizational pattern - amplifier/intensifier pattern - homeostatic pattern. The configurations of the paternal triads of the economic system manifest themselves in a quadra of hierarchical levels: micro-, meso-, macro- and mega-levels. The micro-level represents the basic paternal business triads; the meso-level represents the trialectic configurations of state structure; the macro-level represents the paternal trialectic of sociocultural fluctuations of economic systems; the mega-level represents the trialectic of the projects of the cultural dominant paradigm. The seven-phase cycle of sociocultural dynamics in the paradigmatic-father plane of static and economic efficiency at the macro- and mega-levels of civilization "West" is considered. A notion of the formation of a nooeconomy of ideative type culture was created, in which human cognitive abilities will act as the main economic evolutionary resource, and knowledge workers as carriers of the ideative cultural mentality will be the meritocratic social class. The concept of the sixth technological structure of NBIS-convergence is seen as the first phase of the culture of the ideological type of cognitive economic systems. The noosphere is interpreted as an attraction-fluctuation manifestation of the phase of transition to the ideative cycle of cultural development by the paternal matrix of the cognitive resources of the dominant culture's core. The added value of cognitive resources within the marginal cost of intellectual capital will lie in the expanding potential of the filter of individual consciousness to unpack the compressed meanings of the semantic vacuum and create texts - innovative and paradigmatic projects of expanded opportunities for life enrichment based on the ontological novelty noumenon-concept of the highest measure of reference and mediator-marker in institutional advanced evolutionary space as cognitive strategic resources of the "advantage of immaturity".
\end{abstract}

Key words: paradigm, pattern, attractor, axiological narrative, sensuous culture, ideative culture, cognitive resources, conscience filter.

JEL Classifications: A13, B49, O39, P16, P49, Z10

\section{Introduction}

The logic of the search for the foundations of economic well-being has consistently reached such a parameter as "culture". If economic institutions are models of economic relations, what precisely determines institutional complementarity and fills

\footnotetext{
Corresponding author:

${ }^{1}$ Lviv University of Trade and Economics, Ukraine.

E-mail: kutsykpetro@gmail.com

ORCID: https://orcid.org/0000-0001-5795-9704

ResearcherID: G-9204-2019

${ }^{2}$ Lviv University of Trade and Economics, Ukraine.

E-mail: bmshevchyk@gmail.com

ORCID: https://orcid.org/0000-0002-0004-325X

${ }^{3}$ Lviv University of Trade and Economics, Ukraine.

E-mail: olenaspr@gmail.com

ORCID: https://orcid.org/0000-0001-5784-1490
}

the content of industrial paternalistic practices and distributions? That is, there is a social factor of biodiversity, which simultaneously determines the specifics of the way of comprehending wellbeing - culture - an individual feature of the historical existence of each people, reflecting and determining 
the unrepeated interconnections of man and the world. The object of this study is culture as an integral factor of well-being. The subject of the study is the process of socio-cultural dynamics of economic systems, where paternal projects are actualized and ontological preconditions for alternative projects of innovative development are formed in economic practices through a triadic algorithm in the poly attractive space.

\section{Analysis of the recent researches and publications}

The theoretical basis of the study is as follows: V. Nalimov probability theory of senses (Nalimov, 2011); Sj. Beugelsdijk and R. Maseland concept of economy as culture (Beugelsdijk, R. Maseland, 2016); P. Mason notion of zero marginal costs under nooeconomic conditions (Mason, 2016); K. Kantor historical-philosophical concept of projectism (Kantor, 2002); J. Shumpeter evolutionary economic theory (Shumpeter, 2011); A. Toffler conception of the paternal triads of the forms of governance (Toffler, 2003); L. Gumiliov idea of the transition phases in the cycle dynamics under the influence of entropy and attractiveness (Gumiliov, 2001); P. Sorokin conception of socio-cultural fluctuations (Sorokin, 2006); M. Kizim and I. Matyushenko theory of techno-convergences and innovative evolutionary waves of economic systems (Kizim, Matyushenko, 2011); an attractive paradigm of energy progress by the Ukrainian School of physical economy (Podolyansky, 2000; Rudenko, 2015).

\section{Purpose and objectives of the research}

Significant influence of culture on the economy, by virtue of which holistic patterns of socio-economic interaction arise on the basis of awareness through cognitive resources of the dominant cultural attractiveness that allows the introduction and implementation of innovative projects at the micro-, meso-, macro- and mega-levels of social development, is the purpose of our study.

Main tasks: demonstration of entropic nature of economic dynamics cycle in static efficiency mode; demonstration of non-entropic nature of consciousness filter able to produce innovative ordered texts; revealing influence of culture on selected potential of consciousness filter due to axiological attractiveness of dominant culture; to reveal the hierarchical nature of attractiveness in the casual-beneficial referential noumen on phenomenon; to subordinate the nature of innovative projects to the phases of the cycle of sociocultural dynamics; to clarify the possibility of outpacing economic development due to the axiological narrative attractiveness of alternative culture, whose paternal projects are not mediated by the simulacrums.

\section{Primary results of the research}

The analysis of culture as a determinant of economic evolution has not been considered in economic research. Moreover - as a driver of outstripping development. Modern analysts are gradually becoming more and more unanimous about the idea that culture itself will relatively soon become determinant in the nature and pace of economic evolution, ceding secondary importance to material resources. In the process of the noosphericization of economic relations the cultural factor will come to the fore.

Economics as a science as a whole acts as the sum of the results of the study of human life in a world of scarcity. The possibility of living in a deficit-free regime looks meaningless from the point of view of the subject of the economy, because there is no other alternative in the conditions of material production and discrete forms of social reproduction (already Aristotle argued that the material is only possible as sporadic, and therefore limited). Thus, everything discrete in physical forms of actualization is rare, and for that reason, valuable; and in the case of limited access, costly, then worthy. Accordingly, the idea of well-being emerges from Schumpeter's technological insider ability of "new combinations", through which innovation multiplies existence, reflected in quantitative macroeconomic indicators, to further acquire a mode of static efficiency in accordance with the Pareto optimum - homeostasis as a goal. And so on until the subsequent bifurcation in the form of an innovative project, the actual acquisitive implementation of which in the sphere of material production serves as a driver of economic development.

On the other hand, the theoretical discourse on the proportionality of economy and culture in the existence of society has both its history and its particularities. The narrative Homo economicus initially incorporates contextual characteristics: back in the days of 17thand 18th-century mercantilism, the cultural was considered a logical-rational thinking polymath with techno-pragmatic knowledge of improving natural chaos to create utilitarian comfort and maximize individual gain. The cultural description of an economic person's pattern of behavior itself represents a "normative standard" (Beugelsdijk, Maseland, 2016), that separates the white Western individual from the flexible, culturally backward "naked savages" (Smith, 2001) of the rest of the world. However, subsequent analysis of the culture of the economic individual reveals a discrepancy between the holistic context of collective cultural identity and the atomized individualism of the rational economic actor. Economists continued to delve into the search for universal laws of economic life that would, on the basis of a few generalizing hypotheses, explain human nature in all reasonable cases of life-supporting 
activity. In contrast, culture, which was seen as a given discrete behavioral paternal reconstruction of a predetermined model of existence in accordance with a particular value imperative of collective identity, inhibiting the creative abilities of the individual in the search for broad opportunities to meet needs, is beyond the scope of professional economists. Culture has come to be interpreted in two contexts: 1) as a limited pattern of collective identity that prevents rational choice of freedom of the broad possibilities of maximizing individual utility; and 2) as a narrative of a single identity based on the pervasive principles of the utilitarian nature of each person as a whole - maxutility.

In today's world, culture not only determines the civilizational zones of possible clashes (Hantington, 2006). Conversely, it serves as a volitional synergistic continuum of economic development, as evidenced by the realized practice of the "flying geese" model (Reinert, 2014) of the "Asian tigers". Few researchers pay attention to the fact that the "flying geese" model is not just an offshore-outsourcing diffusion of technology based on pre-approved and specifically defined areas and boundaries of mutual market space. These are, above all, integral processes in the sphere of cultural identity - and this is the primary reason for their success (which analysts are silent about intentionally or not). But culture should not be understood as a static set of behavioral patterns that recreates the traditional conservative way of life and is the main obstacle to innovative transformations. Culture is a dynamic system (Sorokin, 2006) of a certain constellation of phase transitions in cycles of sociocultural oscillations between bipolar megaattractors of sensual and ideological worldview types. Consequently, the behavioral praxeological patterns of the dominant culture have their own algorithm of modifications, which boils down to the apologetics of Westernization - the ecumenical unification of the utilitarian comfort of everyone around. This algorithm of modifications has a clear evolutionary sequence of behavioral patterns: ascetic-ideological type of cultural identity - pseudo-ideological type - active-sensitive type - cynical-sensitive - active-ideological - passivesensitive - idealistic type of cultural identity (Sorokin, 2006). Sociocultural dynamics proceed in a dichotomous space of attraction, where each attractor is ontologically and relatively constituted by a purely sensual and purely ideative axiological narrative. The very mechanism of sociocultural dynamics of economic systems has a trialectic structure of paternal configurations: organizational pattern $\rightarrow$ intensifier pattern $\rightarrow$ homeostatic pattern. The structure of attractive values of the changing types of dominant culture is also trialectic: axiological narrative $\rightarrow$ paradigmatic project $\rightarrow$ praxeological pattern.
As noted above, the fundamental dialectic of the discourse of economy and culture runs in the range of interpretation of the contradictions between the restrictive role of cultural patterns of economic reproduction and the innovative nature of economic development, which is necessarily reduced to overcoming the limitations of the cultural pattern, preferably - to its complete replacement by the multicultural pattern of nationally anonymized being. Is this really the case? Does Mephistopheles of material prosperity require obligatory sacrifices of the national soul?

The individual is an intelligent human being capable of unpacking the compressed meanings of a semantic vacuum and creating texts through a conscious filter (Nalimov, 2011). Man is a creative being capable of creating texts - a formalized existence through words. The fact of existence multiplied by the word is defined as value. The individual is a spiritual being, down to his own verbal creation, forming a coherent continuum of the total picture of the world reflected in the minds of others and thus enabling through the holotropic volitional range to achieve everyone's desired goal, the referential goal of the majority and the least. This is the way in which the cognitive resource of the collegial will to live, first and foremost, the national idea, is formed.

As a spiritual being, the individual intellectually destructively comprehends the ontological meanings of life and correlates the degree of cognitive capacity with the axiological narratives of the dominant culture. As an intellectual being, humans relate the conceived as logically possible, so meanings, being qualitative, acquire quantitative characteristics of possible actualization (Nalimov, 2011). At this ideational stage, the imaginative reality of the conceived possibility of multiplying existence as innovation requires sifting through the actual filters of the positive experience of the dominant culture of cognitive systems-so paradigmatic projects of economic development are formed. As a creative being, the individual stylizes his text-image, endowed with axiological-positive meaning of ontological novelty and logically-rational projective potentiality, eventually into a "pattern of existence" (Nalimov, 2011), that is a program of praxeological realization of things in being in order to multiply the actual unprecedented. That is, the paradigmatic project of innovative development is modified into a paternal project of economic reproduction, subsequently consolidated through institutions in the finality of paternal practices of economic reality (Kantor 2002). At this stage, the subject of cognition becomes the subject of creative activity, the implementer of its own praxeological pattern of the new modality of socio-economic reality.

The trialectical mechanism of socio-cultural dynamics of economic systems in the bipolar attraction space 
operates at the micro-, meso-, macro- and mega-levels of social reality. At the micro-level in the bipolar diapason "bifurcation-homeostasis" in the catalytic space function business triads of entrepreneurial activity: "new combination" insider (organizational pattern) - venture "market ephor" (pattern intensifier) - marketer (homeostatic pattern). The Schumpeter's innovation, having realized through credit new purchasing power, through the introduction of innovative technology triggers cumulative cycles of increasing profitability and net profit, where the final link in the chain of movement of costs to the consumer is the marketer, who personifies the goal of the leading equilibrium process - appropriation of a share of income from the market value of sales. The capacity of the market, deepening through the process of diffusion of innovation, is continuously accompanied by an equalization of the rate of profit until the marginal productivity of resources becomes equal to the marginal utility of the marginal product they create. The surplus value of production is absorbed by the commodity value of commercial purpose and is reduced to the sum of the price of labor and the price of nature in the form of wages and rents (Schumpeter, 2011). A metamorphosis occurs in the structure of the business triad: the homeostatic pattern (the marketer) acts as an ex-insider of "new combinations" in a new organizational status, bringing the latter to the margins of industrial relations. The system starts to operate in a static efficiency mode according to the Pareto optimum (Huerta de Soto, 2011). While the marketer is not an insider of "new combinations" (he can only offer a new possibility of access to commercial services, but not a project of production of qualitatively new consumer value), so he only ensures the manipulation of simulacra: "option architecture," asymmetric information, nudging technologies, the priority of financial speculation on stock exchanges over real investment in material production, offshore migration of money to low-cost labor enclaves and in underdeveloped countries, etc. Thus, profitability becomes a function of entropy: the polarization of property, the intensification of exploitation and ecological threats, the introduction of "shell" institutions as simulacres of production relations, the search for a new way of extracting rents in an extra-economic way, using the resources of political power, etc. There has been an escalation of fighting between business and labor unions and an increase in government overregulation of economic processes with challenges to the quasi-rental of mediocre public servants, whose numbers are growing, fueling corruption in the administration. The struggle for control moves from the micro to the meso level of the economic system, where the dynamic is the movement of the power triad pattern "power - wealth - knowledge" (Toffler,
2003) in a bipolar space of extractive and inclusive social institutions. At the meso-level, "knowledge" stands out as an organizational pattern, and "wealth" as a homeostatic pattern. A knowledgeable worker an intellectual capable of launching projects of economic evolution not just on the basis of a private type of local market of "new combinations", but of launching new technologies of teleological activation of cumulative circles of increasing profitability, at least at the branch level, represents the subject of the "knowledge" pattern. The knowledge worker puts forward the adoption of innovation and information technologies that contribute to the production of surplus value in a cost-saving environment toward achieving zero marginal cost (Mason, 2016). In this way, information technology displaces labor from material production and distorts pricing mechanisms through fluctuations between labor and cost (because it is impossible to reflect in the cost structure the potential moment in time when an innovative idea comes to a scientist's mind) (Toffler, 2003). Under a possible zero marginal cost, the model of the capitalist system ceases to self-reproduce. In order for the model of "wealth" to further function as a homeostasis of the economic system, it is necessary to find alternative sources of profitability that compensate for the leveling effect of innovation on labor costs - direct labor that creates surplus value. In this regard, there are two ways: either a total commercialization of all spheres of life, which seems problematic and absurd, or the migration of capital to sectors where energy-, labor- and material-intensive industries prevail, that is, to the Third World countries.

If the micro-level paradox is that an economic system in its most perfect state of equilibrium should operate without profit (Schumpeter, 2011), the meso-level paradox is that the development of NBIC-techno-convergence is accompanied by unprecedented property polarization of the modern world according to programmed entropic patterns: "poverty traps" (Sachs, 2011), "resource curse" and "the price of inequality" (Stiglitz, 2011; 2012), "the riddle of capital" (de Soto, 2009), "the blind corner" and "killing the winner" (Reinert, 2014), etc. To the homeostatic capacity of the "wealth" pattern is added the "power" pattern, which acts as a protectiveelective resource of rent extraction, relating to the profitable energy-intensive sectors of mining and agriculture. The system aspires to self-sufficiency in the homeostatic regime of the "iron law of oligarchy" (Acemoglu, Robinson, 2016), a pattern of selfreproduction of the ruling power system under any rotation of the power elite. The homeostatic-entropic micro-trap is resolved by attractive meso-level narratives, above all by the introduction of socioeconomic institutions that allow not only the solution of the "riddle of capital" - by applying representative 
property documentation-to translate "garbage into commercial profit" (de Soto, 2009), and propose innovative paradigms of economic development (for example, the paradigm of the Ukrainian PodolinskyRudenko school of physical economics) (Podolinsky, 2000) (Rudenko, 2015). Contemporary scholars (Acemoglu, Robinson, 2016) consider the introduction of inclusive economic institutions a spontaneous function of the economic order, random events of "turns of history" (Gumilov, 2001). This has dramatically complicated the mimesis of inclusive institutions into the production relations practices of the host countries, since it is technology, not mentality, that can be borrowed. This means that the pattern of "knowledge" must have the closest ties to the historical experience of freedom-the precedent of institutional inclusiveness enshrined in the patterns of national culture that have been used as a resource for the development of particular people in the past. The axiological narrative of the emergence of the paradigm-innovation project with "open windows possibilities" is in the macro-level attractive environment of predominantly cultural dynamics. The innovation-paradigm of the alternative order of the "knowledge" pattern is the result of oscillating sociocultural dynamics between the poles of rational and ideative types of culture.

Our time is the final phase of the passive-sensual type of culture. The sensual type of culture began its expansion as an alternative to the ideological project of social being, beginning with the Italian Renaissance. It must be emphasized that the core of every paternal culture adapts and assimilates external challenges through the resources of its protective shells: religious, cognitive, and aesthetic (Kantor, 2002). The modern cycle of sensus culture has passed through the triadic phases of its formation, where the bifurcation first took place in the aesthetic sphere the art of the Italian Renaissance. Then the processes of containment of mental-sensual models of culture gradually took place in the religious sphere from the cynical-sensual to the active-sensual phase - the German Reformation, in the cognitive sphere - the French Enlightenment, but the final transformation of the paradigmatic project into the paternal one occurred in the form of the English industrial revolution. Thus, if the past cycle of the formation of ideological culture was realized by the core religious shell of paternal culture, through which the Western Christian civilization of the medieval period was formed; if the modern cycle of sensual culture has been realized by the aesthetic shell, like the art of the Italian Renaissance, then the future cycle of ideative culture will be simultaneously realized by the cognitive sphere of the core of paternal culture through scientific and technological progress, and to describe these irreversible processes there is a term - noosphere.
Moreover, there is a future synergistic project of the so-called sixth technological mode of NBICconvergence (Kizim, Matyushenko, 2011) in the midst of the still dominant sensual culture. The interpretation of this project from the narrative-axiological positions of the sensuous cultural mentality seems ridiculous: by applying nanotechnologies of atomicmolecular construction and control to a biological organism made of inorganic materials, and then "embedding" integrated circuits into this hybrid material with the intention of creating artificial intelligence, which will act as a powerful duplicate of the human brain - all designed to erase the difference between a human and a robotic device, to cause an uprising of post-android bio-cyborgs, who through bio-nano-manipulations with living and non-living matter will be endowed with the potential for immortality. That is, NBIC-techno-convergences will so improve the conditions of human existence that it will turn into a post-human, who will live relatively forever (Kizim, Matyushenko, 2011). As is evident, the axiological narratives of sentient cognitive resources focus on "improving the conditions of the individual", but not on the evolution of the individual himself. No one talks about what a biocyborg android "great ape" (Buchman, 2003) will do with its immortality? What content will the posthuman life have in its earthly eternity? The subject of a rational cultural mentality does not see the prospects of such challenges, because it does not distinguish simulacrum - entropic patterns of meaningless existence - in the axiological dimension of its own consciousness, where it is cadaveric death rather than immortality of the soul that serves as the ultimate parameter of existence.

Cardinally wrong sounds the narrative of the sixth technological mode in the aspect of ideative culture the goal of technoconvergence is not the criterion of biological immortality, but the maximum possible liberation of the individual from the need for material production and strict orientation of human cognitive potential on the ontological causes of existence, the creation of such texts, which will carry knowledge of the higher purpose of human existence on Earth. The use of nano-, bio-, info- and cognitive technologies will make it possible to produce economic values in the mode of maximum approximation to zero marginal cost, and then socially necessary labor, freed from the composition of costs, will be applied where no machine can replace man - in the artistic creation of spiritual multiplication of being, in the evolving ability of the conscience filter to unpack such semantic vacuum meanings, where the word-image texts will contain the holotropic content of the possibilities of existence in the synchronic-referential dimension of the Creator and the Universe. In this case, economic activity will become synonymous with artistic creativity, and exchange transactions will depend only 
on the degree of ontological novelty of the use value of the word in the direction of the growth of this holotropic metaphysical referentiality in the consciousness of the user of the word.

A macro-level attractive source of sociocultural fluctuations of economic systems is the mega-level of civilizational dominants. At the mega-level, the idea of time in its historical meaning as chiliastical and eschatological serves the subject of being (Bulgakov, 2006). The urgic type of sensual cultural mentality is subjected to a chiliastical understanding of the world. A chiliastical axiology of history envisions an evolutionary and linear paradigm of time - eternal becoming without higher practicality. Being as genesis is provided by the urgic patterns of mentality, a combination of utilitarian narratives of organizing the artificially shaped world as mechanical equipment. Here there is no holotropic comprehension of being, and integration is reduced to a quantitative semblance of essentially impersonal being, that is, the simulacrum acts as the vital principle. Apocalyptic axiology is not reduced to the concept of the end (the end of history, the end of the world, the apocalypse of civilization, etc.), but to the idea of an eternally new beginning of infinite perfection, the search for the primary unity of all things, which is achieved by the gonic way, the worldview - because all created things are generated from one Original Source, and each particle is inherently a fractal of the Whole, hence each individual being has absolute value, so time has the cyclic nature of the "Great Conversion" of each "mustard seed," realizing possibility-calling in the direction of godless perfection of being.

\section{Conclusions and recommendations}

The cultural content of economic relations reveals features that remain beyond the vision of traditional economic methods. Culture is not only a component of the metrological analysis of economic systems, which reveals possible external effects, a peculiar locality of time and place. Although culture determines the qualitative characteristics of human and social capital, including its synergy-integrative potential, it reflects the archetypically narrative circumstances of institutional complementarity, which ensures the success of economic projects, above all - innovation. So, since culture defines the axiology of paradigmatic design, on the one hand, and the synergetic potential of the identity realized by the will - on the other hand, it serves as a fundamental condition for the realization of the advanced development on the basis of those "advantages of backwardness", which in sociocultural fluctuations processes represent the cognitive resources of formation of the organizational scheme project of innovative economic order.

The concept of advanced development of economic development in the socio-cultural context is resolved into a hierarchy of coherent attractiveness at the micro-, meso-, macro- and mega-levels of socioeconomic being, where the higher level serves as an attractive environment for the lower level, accumulating in itself the values and goals. The prospect of the formation of ideological culture samples, as an organizational culture, in the near future will provide such gaps of economic opportunities, where the production technologies of innovation will be focused on the identification of ontological meanings of higher referential degree of metaphysical ideal concept of being and images-mediators of its praxeological actualization, which will serve as the essential-substantial basis of economic value of future noo-economic intellectual production.

\section{References:}

Acemoglu, D., \& Robinson, J. (2016). Chomu natsii zanepadaiut. Pohojennia vlady, bahatstva ta bidnosty [The Origins of Power, Prosperity, and Poverty]. Kyiv: "Nash format".

Beugelsdijk, Sj., \& Maseland, R. (2016). Kultura w ekonomicheskoy nauke: istoria, metodologicheskie rassuzhdenia I oblasti prakticheskoho primenenia w sovremennosty [Culture in Economics: History, Methodological Reflections, and Contemporary Applications]. Sankt-Peterburg: "Isdatelstvo Instituta Gaidara".

Buchanan, P. (2003). Smert Zapada [The Death of the West]. Moscow: "Izdatel'stvo ACT".

Bulgakov, S. (2006). Rozmysly. Tvorcha spadshchyna u konteksty stolittja [Creative Heritage in the Context of the 21 st Century]. Kyiv: "Znannia".

Gumiliov, L. N. (2001). Ethnogenez i biosfera Zemli [Ethnogenesis Biosphere and Earth]. Moscow: OOO "Publishing AST".

Huntington, S. (2006). Protystojannia tsyvilizatsij ta zmina svitovoho poriadku [The Clash of Civilizations and the Remaking of World Order]. Lviv: "Kalvariia".

Huerta de Soto, E. (2011). Sotsialno-ekonomitcheskaia teoria dinamicheskoij effektyvnosty [The Theory of Dynamic Efficiency]. Tcheliabinsk: "Sotsium".

Kantor, K. (2002). Dvojnaja spiral' istorii: Istoriosophiya proektyzma. T. 1. Obshchiye problemy [The double helix history: Historiosophy proectism: general issuese Curse]. Moscow: "Izdatel'stvo Jzyki slavianskoy kultury". 
Kizim, M. O., \& Matyushenko, I. Yu. (2011). Perspektyvy rozvytku i komercializacii nanotekhnologij $v$ ekonomikach krain svitu ta Ukrainy [Prospects of development and commercialization of nanotechnologies in the world's countries economies and Ukraine]. Kharkiv: "VD "INZHEK".

Meyson, P. (2016). Postkapitalizm: putevoditel po nashemu budushchemu [PostCapitalism: A Guide to Our Future]. Moscow: Ad Marginem Press.

Nalimov, V. (2011). Spontannost soznanija [Spontaneity of Consciousness]. Moscow: "Akademychesky Proekt: Paradygma".

Podolynsky, S. (2000). Vybrany tvory [Works are Chosen]. Kyiv: "KNEU".

Reinert, E. (2014). Chomu bahaty krainy zabahatily... i chomu bidni krainy zalyshaiytsia bidnymy [As Rich Countries Got Rich and why Poor Countries Remainpoor]. Kyiv: "Tempora".

Rudenko, M. (2015). Energija progresu: Vybrany pratcy z ekonomiyi, filosofyi I kosmolohyi [Energy Progress: Selected Works of Economy, Philosophy and Cosmology]. Kyiv: TOV "Vydavnytstvo "Klio".

Sachs, J. (2011). Konets bednosti. Ekonomicheskije vozmozhnosty nashego vremeny [The End of Poverty. Economic Possibilities for Our Time]. Moscow: "Izdatelstvo Instituta Gaidara".

Shumpeter, J. (2011). Teorija ekonomichnoho rozvytku. Doslijen'ya prybutkiv, kapitalu, kredytu, vidsotka ta ekonomichnoho tcsiklu [The Theory of Economic Development. An Inquiry info Profits, Capital, Credit, Interest, and the Business Cycle]. Kyiv: "Wydavnychiy dim "Kyivo-Mohyl'ias'ka akademiya".

Smith, A. (2001). Dobrobut natzij [The Wealth of Nations]. Kyiv: "Port-Poyal".

Sorokin, P. (2006). Social'naya i kulturnaya dynamika [Social and cultural dynamics]. Moscow: "Izdatel'stvo Astrel'". Soto de H. (2009). Zahadka kapitalu. Chomu kapitalizm peremahaie lyshe na Zahody i nide bilshe [The Mystery of Capital. Why Capitalism Triumphs in the West and Fails Everywhere Else]. Kyiv: "Nika-Tsentr".

Stiglitz, J. (2011). Kak izbezhat resursnogo prokliatija [Escaping the Resource Curse]. Moscow: "Izdatelstvo Instituta Gaidara".

Stiglitz, J. (2017). Tsina nerivnosty [The Price of Inequality]. Kyiv: "Tempora".

Toffler, A. (2003). Nova paradyhma vlady: znannya, bahatstvo, syla [Powershift: Knowladge, Wealth, and Violence at the edge of the 21 st century]. Kyiv: "Akta". 